\title{
ИСПОЛЬЗОВАНИЕ СТИМУЛЯТОРОВ КОРНЕОБРАЗОВАНИЯ В ЗЕЛЕНОМ ЧЕРЕНКОВАНИИ СОРТОВ СМОРОДИНЫ ЧЕРНОЙ В УСЛОВИЯХ СРЕДНЕТАЕЖНОЙ ПОДЗОНЫ РЕСПУБЛИКИ КОМИ
}

\author{
О.К. Тимушева \\ Федеральное государственное бюджетное учреждение науки \\ Институт биологии Коми научного центра Уральского отделения РАН, Сыктывкар \\ E-mail: otimusheva@ib.komisc.ru
}

\begin{abstract}
Аннотация. В статье представлены результаты вегетативного размножения методом зеленого черенкования в 2016 г. пяти сортов смородины черной (Ribes nigrum L.) алтайской (Сеянец Голубки), московской (Вологда и Наследница), мичуринской (Зеленая Дымка) и орловской (Лентяй) селекций в условиях среднетаежной подзоны Республики Коми. С целью оценки характера влияния стимуляторов корнеобразования на приживаемость зеленых черенков при размножении были использованы стимуляторы корнеобразования корневин и эпин-экстра (эпин). Выявлен положительный эффект действия корневина и эпина на укоренение и приживаемость. Произведена группировка сортов смородины в зависимости от характера приживаемости черенков и роли стимуляторов. Выделены наиболее перспективные с точки зрения изучаемых признаков сорта для выращивания в климатических условиях Республики Коми.
\end{abstract}

Ключевые слова: смородина черная, вегетативное размножение, зеленое черенкование, корневин, эпинэкстра, укореняемость, приживаемость

\section{Введение}

Смородина черная Ribes nigrum L. относится к семейству Grossulariaceae DC., подроду Eucoreosma Jancz. (черные смородины) рода Ribes L. Данный подрод включает 20 видов и имеет практическое и селекционное значение. Смородина растет в большинстве районов Евразии и Северной Америки (исключая южные районы и Арктику) (Витковский, 2003).

Смородина является одной из ведущих ягодных культур России и стран Европы. На территории Республики Коми произрастает четыре вида смородины, в том числе Ribes nigrum L. - смородина черная (Мартыненко, 2008). Смородина черная является евро-азиатским видом (Атлас ареалов ..., 1983), это типичное лесное растение. В Республике Коми смородина черная произрастает в приручейных смешанных лесах, пойменных ельниках, осинниках, ольшаниках, лесных оврагах, по краям низинных болот, на вырубках и гарях, иногда образуя заросли (Мартыненко, 1976).

Плоды смородины из-за своего биохимического состава полезны для здоровья человека как непосредственно при употреблении в пищу, так и после переработки в той или иной форме. Ягоды смородины черной ценят за высокое содержание аскорбиновой кислоты (витамина С) - до 340 мг\%. В состав ягод входят от 6.25 до $10.26 \%$ сахаров, от 2.13 до $3.39 \%$ органических кислот. Ягоды содержат витамины $\mathrm{P}, \mathrm{A}, \mathrm{E}, \mathrm{B}_{1}, \mathrm{~B}_{2}, \mathrm{~B}_{3}, \mathrm{~B}_{6}$, $\mathrm{B}_{9}, \mathrm{PP}, \mathrm{K}$, соли калия, железа, кальций, фосфор, магний. Они богаты пектиновыми, дубильными, азотистыми веществами, флавоноидами, антоцианами (Жулева, 2005). Помимо этого, ягоды обладают противораковыми свойствами, что дает возможность использовать плоды смородины в создании препаратов, препятствующих развитию онкологических заболеваний, в особенности рака печени (Anthocyanin-rich ..., 2011; Radical scavenging ..., 2012). Экстракт ягод смородины черной на клеточном уровне уменьшает негативное влияние активных форм кислорода, ведущее к гибели клеток (Protective effects ..., 2014). Ягоды смородины при поддержании соответствующих внешних условий способны сохранять полезные вещества в течение нескольких месяцев (Bakowska-Barczak, 2011).

Богаты полезными веществами также листья и почки смородины черной (Variations ..., 2009). Они содержат антиоксиданты, например, Ribe$\sin \mathrm{D}$ и Ribesin G (Antioxidant lignoids ..., 2013), флавоноиды (Antioxidant ..., 2012). Состав и структура флавоноидов существенно различаются в зависимости от сорта растения (High variability ..., 2016). Листья содержат витамин C, каротин, фитонциды, эфирные масла (Жулева, 2005). Листья и почки смородины помимо многих других компонентов содержат витамин С и фенольные соединения (Liu, 2014; Major phenolic ..., 2015), максимально накапливающиеся в растении под действием солнечного света (Influence of shading ..., 2013; Effects of controlled ..., 2015) и при относительно низкой температуре воздуха.

Сорта смородины черной крайне разнообразны по своим характеристикам - урожайности, составу биохимических компонентов и др. (Ротоlogical ..., 2014).

Полезные свойства и вкусовые качества растения обусловливают интерес к нему со стороны промышленных предприятий, мелких фермерских хозяйств и садоводов-любителей. Данное обстоятельство делает актуальным исследование биологии различных сортов смородины в условиях среднетаежной подзоны Республики Коми.

Для получения качественного посадочного материала культурных растений смородины целесообразно осуществлять вегетативное размножение перспективных сортов смородины путем образования нового растения из части материнского в результате отделения жизнеспособных час- 
тей вегетативного тела растения (почек, побегов, корней и т.д.) (Батыгина, 2002). Для улучшения корнеобразования широко используются стимуляторы роста. Некоторые экологически безопасные препараты, в числе которых эпин, циркон, высоко эффективны в качестве стимуляторов корнеобразования и могут заменить синтетические ауксины ( $\beta$-ИУК, $\beta$-ИМК), широко применяемые в технологии зеленого черенкования. Укореняемость должна быть не менее 60-90\%, а выход стандартных саженцев - не ниже 30-40\% от исходного числа черенков (Аладина, 2013). Вегетативное размножение позволяет получать однородное потомство плодовых и ягодных растений и сохранять ценные качества форм и сортов. Одним из эффективных способов является метод размножения зелеными черенками. Регенерация при зеленом черенковании проявляется неодинаково и зависит от многих факторов: жизненной формы, наследственных особенностей, возраста, состояния маточных растений, условий укоренения и пр. Растения на ранних стадиях своего онтогенеза проявляют высокую регенерационную способность, которая в дальнейшем, по мере старения, снижается. В связи с этим маточники в зависимости от жизненной формы растений целесообразно использовать до 5-12-летнего возраста (Аладина, 2013).

Целью работы является изучение влияния стимуляторов корневин и эпин-экстра (эпин) на корнеобразование и приживаемость после посадки зеленых черенков сортов смородины черной в подзоне средней тайги Республики Коми с группировкой сортов в зависимости от значения (в \%) приживаемости, влияния стимуляторов и перспективности выращивания в климатических условиях Республики Коми.

\section{Материалы и методы}

Объектами исследований были пять сортов смородины черной различной селекции: алтайской (Сеянец Голубки), московской (Вологда и Наследница), мичуринской (Зеленая Дымка) и орловской (Лентяй). Данные сорта являются продуктивными, крупноплодными и перспективными для выращивания в среднетаежной подзоне Республики Коми. Исследуемые сорта по генетической группе являются сортами-гибридами между европейским и сибирским подвидами смородины черной и смородиной дикушей: Ribes nigrum ssp. europaeum Jancz. $\times$ Ribes nigrum ssp. sibiricum E. Wolf. $\times$ Ribes dikuscha Fisch. (Огольцова, 1992).

Исследования проведены в окрестностях Сыктывкара в Ботаническом саду Института биологии Коми НЦ УрО РАН. Данная территория относится к достаточно увлажненному району, среднегодовая сумма осадков здесь 500-600 мм, из которых 400-450 мм выпадает в теплый период года (Атлас ..., 1997). Почвы на участке ботанического сада в основном дерново-подзолистые, глееватые, среднеокультуренные, суглинистого механического состава.
Исследования проводили в 2016 г. Среднегодовая температура в этот период составила $1.9{ }^{\circ} \mathrm{C}$, что выше нормы $\left(0.3{ }^{\circ} \mathrm{C}\right)$. Июль оказался жарким: среднесуточная температура воздуха составила $19.9{ }^{\circ} \mathrm{C}$, что выше нормы на $3.3^{\circ} \mathrm{C}$. В июле выпало 70 мм осадков, что близко к норме. Вегетационный период в 2016 г. продолжался 173 дня, что на 23 дня больше нормы; сумма эффективных температур (выше $5{ }^{\circ} \mathrm{C}$ ) составила $2430{ }^{\circ} \mathrm{C}$ (в 2.3 раза больше нормы). Сумма активных температур выше $10{ }^{\circ} \mathrm{C}-2045^{\circ} \mathrm{C}$ (в 1.4 раза больше нормы). В первой декаде июля, когда был проведен опыт с зеленым черенкованием, среднесуточная температура воздуха была $+19.6^{\circ} \mathrm{C}$. Разница между максимальной и минимальной температурой воздуха в данной декаде составила $15.9{ }^{\circ} \mathrm{C}$. Было отмечено восемь дней с дождями (18 мм). В целом, погода для укоренения черенков была благоприятной.

Для изучения черенков использовали методические указания ВНИИР им. Н.И. Вавилова (Плеханова, 1989). В ходе исследования определяли динамику корнеобразования у зеленых черенков: число корней нулевого порядка, суммарную длину корней нулевого порядка, число корней первого порядка (через 50 дней после посадки, во второй декаде августа).

В первой декаде июля 2016 г. было проведено зеленое черенкование пяти сортов смородины черной в холодный парник. Кусты смородины, от которых брали зеленые черенки, были посажены 19-20 лет назад. Зеленые побеги сортов брали в утренние часы, затем их нарезали на черенки длиной от 12 до 16 см с тремя-пятью почками. Всего было исследовано по 27 черенков каждого сорта.

Субстратом для черенков была смесь речного песка с торфом в пропорции 1:1. Субстрат насыпали поверх торфоперегнойной земли слоем 3.54.0 см. Схема посадки: $20 \times 5$ см. На следующий день после обработки черенки высаживали в парник на глубину 2 см наклонно под углом до $45^{\circ}$ во влажную почву. Сверху черенки укрывали материалом «Агротекс» и обильно поливали водой.

Стимуляторами корнеобразования в опыте служили препараты корневин и эпин-экстра (эпин). В качестве контроля использовали дистиллированную воду. Смоченные в воде черенки перед посадкой погружали нижней частью в препарат корневин (представляет собой порошок). Раствор эпина был приготовлен согласно инструкции (1 мл на 2 л воды). Черенки выдерживали в эпине 20 ч при температуре раствора $20-24{ }^{\circ} \mathrm{C}$ и на следующий день высаживали.

В процессе получения результатов и их оценки в соответствии с целью исследования использовали регистрацию наблюдений, графический метод представления и анализа собранной информации, методы группировки, сравнения и расчета показателей, характеризующих разброс данных в совокупности (средняя, стандартные отклонения и ошибка). 
Целесообразность использования стимуляторов корнеобразования тестируется в данной работе по признакам числа и длины корней нулевого порядка черенков по методике, применяемой при статистической оценке значимости различий между генеральными совокупностями по средним их выборок. Оценка существенности отличий между двумя совокупностями выполнена с помощью критерия существенности разности средних двух наборов данных при наличии несопряженных (независимых) выборок (Доспехов, 1985; Рязанова, 2013). В данной работе единицами совокупностей выступают регистрируемые данные о числе и длине корней по каждому из пяти наблюдаемых сортов смородины черной после использования стимуляторов корнеобразования и выдержки черенков в контроле.

\section{Результаты}

В укоренении зеленых черенков определяющую роль играет срок черенкования. В условиях подзоны средней тайги Республики Коми лучшим сроком зеленого черенкования является перваявторая декада июля в зависимости от погодных условий (Тимушева, 2012).

Процесс корнеобразования начался спустя 1618 дней. Через три недели после посадки, в третьей декаде июля (22.07), мы отмечали процент укоренившихся черенков, через семь недель после посадки (19.08) - процент приживаемости от числа высаженных черенков. В конце второй декады августа случайным образом были отобраны по три черенка каждого сорта, определено число корней нулевого и первого порядков, а также измерена длина корней нулевого порядка.

Регенерация черенков - образование корней произошла через 16-18 дней после высадки черенков в субстрат. Сначала появился каллус: опробковевающая ткань, которая возникла в результате деления пограничных с раной клеток. Затем выросли корни нулевого порядка. Регенерация зависит от температуры субстрата и воздуха в зоне черенков (должна быть выше $20{ }^{\circ} \mathrm{C}$ ) и влажности воздуха (выше $90 \%$ ). В нашем опыте укоренилось в среднем $64-77 \%$, прижилось $46-$

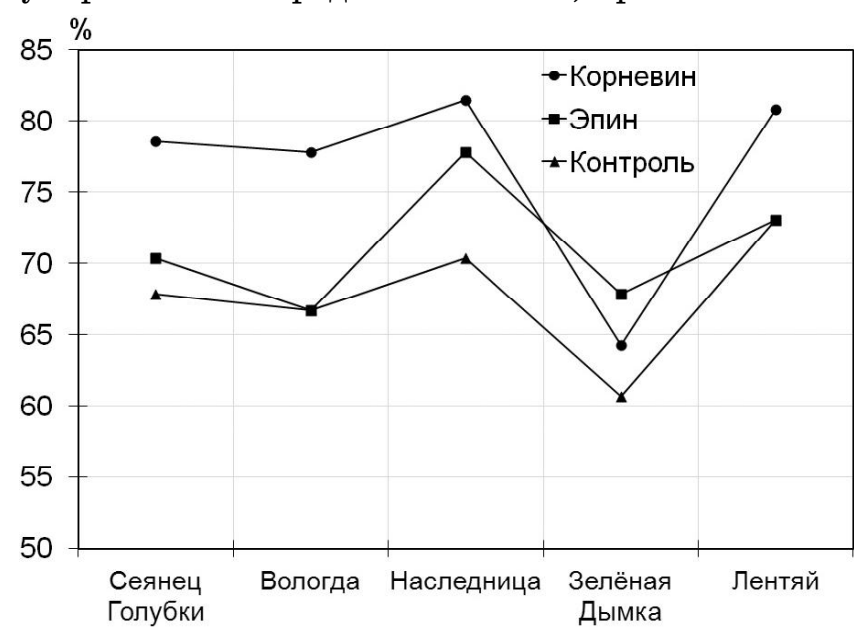

Рис. 1. Укореняемость зеленых черенков (22 июля), \%.
$52 \%$ черенков от числа высаженных в контроле и стимуляторах корнеобразования, учитываемых вместе. Не учитывая результат по контролю, укоренилось в среднем $66-80 \%$ и прижилось $48-$ $56 \%$ черенков от общего числа высаженных.

В среднем по пяти сортам укореняемость зеленых черенков в корневине оказалась выше по сравнению с контролем на $13 \%$, с эпином - на $8 \%$ (рис. 1).

Укореняемость черенков в корневине больше, чем в эпине и контроле, за исключением сорта Зеленая Дымка.

По сорту Зеленая Дымка укореняемость в эпине превышает укореняемость в корневине на $6 \%$. По сравнению с контролем, укореняемость сортов Зеленая Дымка и Наследница в эпине также заметно выше (на $12 \%$ ), но по остальным трем сортам (Лентяй, Сеянец Голубки и Вологда) применение эпина не дает заметного эффекта укореняемости.

В целом, увеличение укореняемости черенков в результате применения корневина заметно при сравнении с контролем, однако при сравнении корневина и эпина, а также эпина и контроля, нельзя сделать однозначные выводы о преимуществе какого-либо стимулятора. Применение корневина представляется целесообразным при размножении сортов Сеянец Голубки, Вологда и Лентяй.

Приживаемость зеленых черенков при применении стимуляторов корнеобразования оказалась выше, чем в контроле, за исключением сорта Лентяй. Если приживаемость черенков в контроле составила от 39 до $54 \%$ от общего числа высаженных черенков, то приживаемость в корневине - от 46 до 61, эпине - от 46 до $56 \%$ (рис. 2 ).

Приживаемость черенков в корневине была больше по сравнению с эпином и контролем по сортам Сеянец Голубки и Вологда и оказалась максимальной среди всех сортов и стимуляторов (здесь прижилось свыше $55 \%$ от числа высаженных черенков). По сорту Лентяй наиболее предпочтительной средой в итоге оказалась вода (контроль), несмотря на существенно лучшую укореняемость черенков данного сорта в корневине.

По сортам Наследница и Зеленая Дымка наилучшая приживаемость была достигнута при применении эпина. Для сорта Зеленая Дымка результат по итогам этапа укоренения (в части лучшего стимулятора) совпал с выводами по итогам приживаемости черенка.

В целом, применение корневина и эпина оказывает благоприятное воздействие на приживаемость черенков, но, в отличие от оценки эффекта стимуляторов на этапе корнеобразования (укореняемости), для этапа приживаемости данный вывод менее очевиден. При воздействии корневина приживаемость в количественном выражении оказывается максимальной (при применении к конкретным сортам), но по отдельным сортам применение стимуляторов может и вовсе не дать положительного эффекта (сорт Лентяй). Таким 
образом, различия в степени воздействия стимуляторов на показатели приживаемости черенков в сравнении с контролем постепенно уменьшаются, хотя их применение продолжает оказывать положительный эффект. Как на этапе укоренения, так и на этапе приживаемости черенков действие стимуляторов корнеобразования примерно сопоставимо между собой - результаты опыта не позволяют говорить о предпочтительности использования какого-либо конкретного стимулятора при размножении зеленым черенкованием и выбор зависит от сорта смородины.

Применение стимуляторов корнеобразования положительно сказывается на числе корней нулевого и первого порядков вне зависимости от сорта смородины (рис. 3, общая статистика - в справочной части Приложения). При использовании стимулятора (корневина или эпина) образуется заметно большее число корней, чем при выдержке черенка в контроле (воде). Так как число корней первого порядка зависит от числа «нулевых» корней, значимость стимуляторов для числа корней первого порядка выражена еще более ярко.

Максимальное число корней нулевого порядка (в среднем как по всем трем средам, так и по стимуляторам) наблюдалось у сорта Вологда; оно было больше, чем у сортов с наименьшим числом корней - Зеленая Дымка и Лентяй - примерно в 1.5-2.2 раза соответственно. Таковы же соотношения числа корней первого порядка у изучаемых сортов.

В среднем от каждого корня нулевого порядка образуется 9-12 корней первого порядка, и в данном аспекте влияние стимуляторов не отличается от контроля. В то же время черенки сорта Сеянец Голубки при воздействии стимуляторов корнеобразования формируют наибольшее среди сортов число корней первого порядка (примерно 1112 шт.), особенно в сравнении с сортом Наследница. Рост корней первого порядка при воздействии стимуляторов наблюдается также у сорта Вологда. Таким образом, для некоторых сортов положительное влияние стимуляторов выражается в увеличении числа корней первого порядка.

Оценка существенности отличий между числом образовавшихся у черенка корней нулевого порядка и средней длиной корня при применении стимулятора корнеобразования (корневина или эпина) или обычной выдержке черенка в контроле (воде) осуществляется с помощью расчета критерия существенности разности средних двух наборов данных.

Применение стимуляторов корнеобразования корневина и эпина положительно влияет на образование корней нулевого порядка у рассматриваемых сортов смородины черной и данное влияние статистически значимо (табл. 1). Более значительно влияние стимуляторов для сортов Наследница и Лентяй (максимальные относительно остальных сортов значения по показателю $\mathrm{t}_{\text {факт }}$ ).

По всем пяти сортам смородины черной влияние корневина на образование корней нулевого

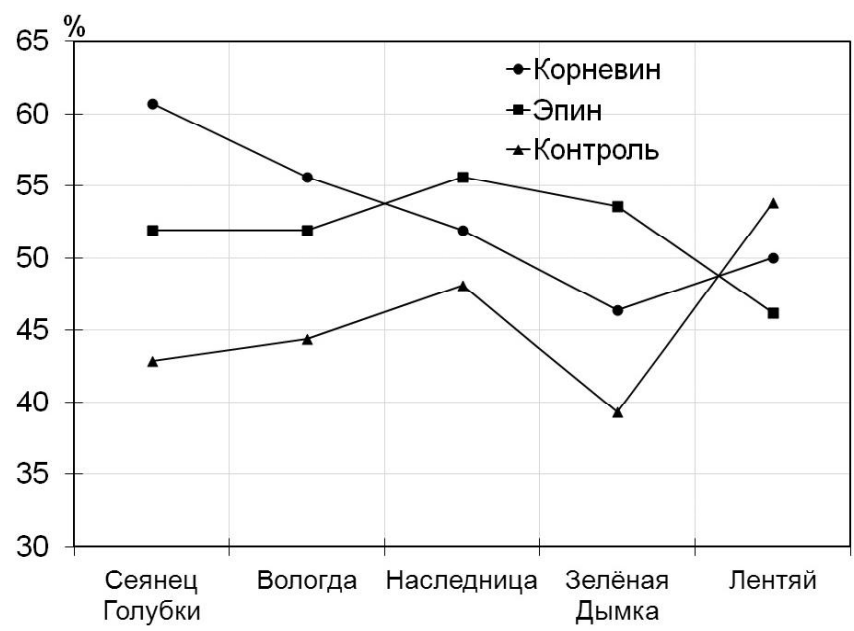

Рис. 2. Приживаемость зеленых черенков (19 августа), \%.

порядка оказывается более сильным, чем эпина (расчетные значения $\mathrm{t}_{\text {факт }}$ по корневину заметно превышают аналогичные величины по эпину). Расчеты по эпину по ряду сортов (Сеянец Голубки, Зеленая Дымка, Вологда) едва превышают контрольное значение $\left(\mathrm{t}_{\text {табл }}\right)$, равное 2.78. Это говорит о более слабой роли данного стимулятора в корнеобразовании и потенциальном выводе о незначимости эпина при увеличении доверительной вероятности расчетов (превышения текущей нижней границы в $95 \%$ ).

Менее однозначные выводы о роли стимуляторов корнеобразования можно сделать относительно показателя средней длины корня нулевого порядка у черенка. Для большинства рассматриваемых сортов применение стимуляторов корнеобразования положительно сказывается на средней длине корня черенка вне зависимости от сорта смородины (рис. 4). Исключение составляет сорт Вологда, у которого средняя длина корня в контроле превышает длину корней в корневине и эпине.

Рассматриваемые сорта не показали заметных различий по значению показателя средней длины корня. Для всех сортов без учета среды она составляет около 9 см, при этом для четырех из

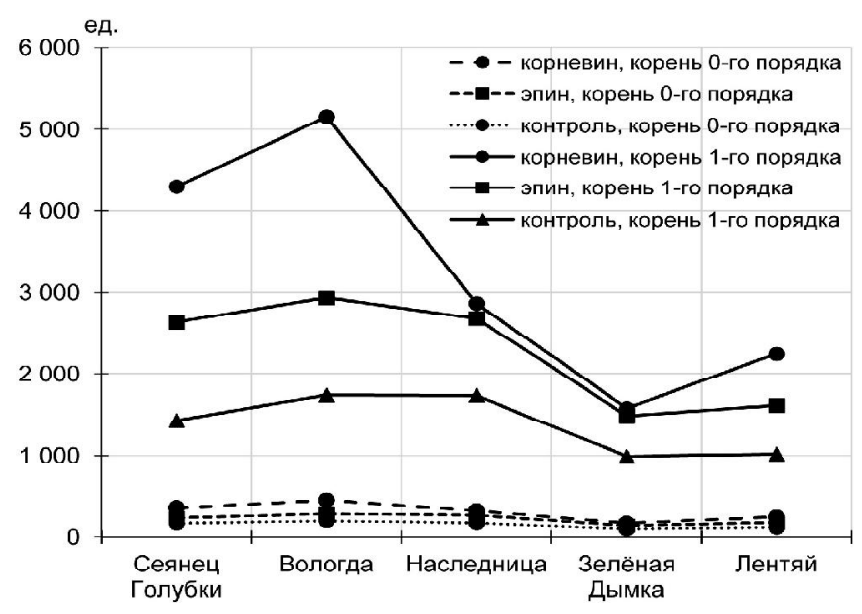

Рис. 3. Число корней нулевого и первого порядков, ед. 
Анализ влияния стимулятора корнеобразования на число корней нулевого порядка

\begin{tabular}{|c|c|c|c|c|c|}
\hline Сорт & Пара выборок & $\begin{array}{c}\text { Разница между } \\
\text { средними двух } \\
\text { выборок }\end{array}$ & $\begin{array}{c}\text { Ошибка разности } \\
\text { средних по двум } \\
\text { выборкам } \\
\end{array}$ & $\begin{array}{c}\text { Критерий } \\
\text { существенности } \\
\text { разности ( } \mathrm{t}_{\text {факт) }}\end{array}$ & $\begin{array}{c}\text { Вывод о влиянии } \\
\text { стимулятора }\end{array}$ \\
\hline \multirow[t]{2}{*}{ Сеянец Голубки } & Корневин/контроль & 63.0 & 7.3 & 8.58 & Значим \\
\hline & Эпин/контроль & 22.0 & 7.3 & 3.00 & Значим \\
\hline \multirow[t]{2}{*}{ Вологда } & Корневин/контроль & 83.7 & 9.5 & 8.80 & Значим \\
\hline & Эпин/контроль & 29.0 & 7.8 & 3.72 & Значим \\
\hline \multirow[t]{2}{*}{ Наследница } & Корневин/контроль & 50.7 & 3.5 & 14.56 & Значим \\
\hline & Эпин/контроль & 32.0 & 4.1 & 7.79 & Значим \\
\hline \multirow[t]{2}{*}{ Зеленая Дымка } & Корневин/контроль & 24.7 & 5.5 & 4.52 & Значим \\
\hline & Эпин/контроль & 14.7 & 4.0 & 3.65 & Значим \\
\hline \multirow[t]{2}{*}{ Лентяй } & Корневин/контроль & 44.0 & 3.5 & 12.59 & Значим \\
\hline & Эпин/контроль & 19.7 & 3.7 & 5.34 & Значим \\
\hline
\end{tabular}

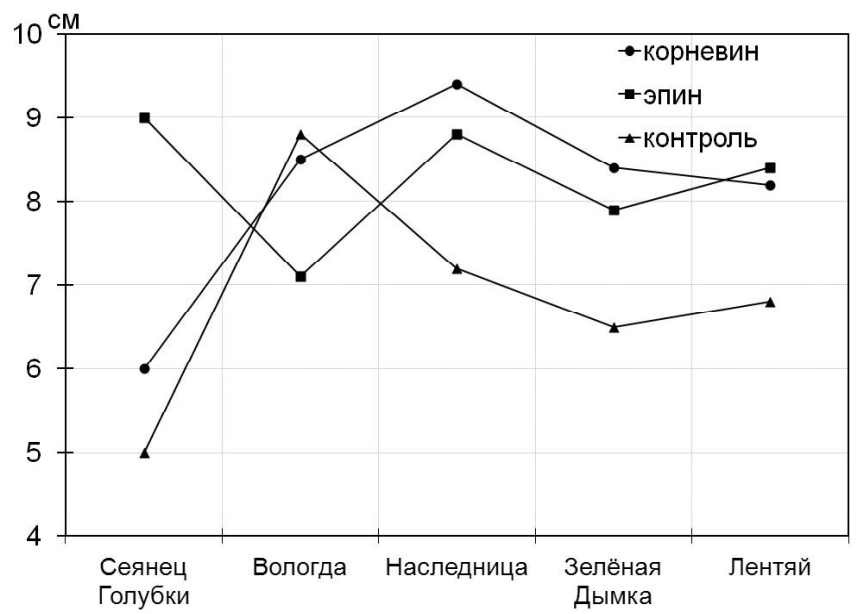

Рис. 4. Средняя длина корня нулевого порядка у черенка, см.

пяти сортов разница в средней длине корня в зависимости от среды составляет не более 2 см. Выбор стимулятора зависит от сорта смородины черной, но актуальным данный вопрос становится только для сорта Сеянец Голубки, где средняя длина корня в контроле составляет около 5 см, в эпине - около 9 см.

Применение стимуляторов корнеобразования корневина и эпина в большинстве случаев положительно влияет на среднюю длину корня нуле- вого порядка у рассматриваемых сортов смородины черной (табл. 2). Значимость стимулятора вне зависимости от его вида наблюдается у сортов Наследница и Лентяй и для данных сортов выводы о значимости стимуляторов наиболее определенные. Не показали статистически значимых различий замеры корней в стимуляторах и контроле у сорта Вологда. Длина «нулевого» корня у черенков сортов Сеянец Голубки и Зеленая Дымка оказалась чувствительной к выбору стимулятора - эпину и корневину соответственно, однако роль эпина для сорта Сеянец Голубки будет нивелирована при увеличении доверительной вероятности свыше $95 \%$.

\section{Обсуждение}

Размножение сортов смородины черной проведено в первой декаде июля - наиболее благоприятном периоде по метеорологическим условиям в среднетаежной подзоне Республики Коми. Этот период опережает на одну декаду срок зеленого черенкования в условиях северо-запада Российской Федерации (Поздняков, 1985).

В нашем опыте корнеобразование началось к началу третьей декады июля, в среднем через 17 дней. В условиях закрытого грунта (в теплице) образование корней наблюдается примерно через 10 дней (Стрельцов, 2008).

Анализ влияния стимулятора корнеобразования на среднюю длину корней нулевого порядка

\begin{tabular}{|c|c|c|c|c|c|}
\hline Сорт & Пара выборок & $\begin{array}{c}\text { Разница между } \\
\text { средними двух } \\
\text { выборок } \\
\end{array}$ & $\begin{array}{c}\text { Ошибка разности } \\
\text { средних по двум } \\
\text { выборкам } \\
\end{array}$ & $\begin{array}{c}\text { Критерий } \\
\text { существенности } \\
\text { разности }\left(\mathrm{t}_{\text {факт) }}\right.\end{array}$ & $\begin{array}{c}\text { Вывод о влиянии } \\
\text { стимулятора }\end{array}$ \\
\hline \multirow[t]{2}{*}{ Сеянец Голубки } & Корневин/контроль & 1.0 & 1.2 & 0.85 & Не значим \\
\hline & Эпин/контроль & 4.1 & 1.4 & 2.82 & Значим \\
\hline \multirow[t]{2}{*}{ Вологда } & Корневин/контроль & -0.3 & 1.2 & -0.21 & Не значим \\
\hline & Эпин/контроль & -1.7 & 1.2 & -1.40 & Не значим \\
\hline \multirow[t]{2}{*}{ Наследница } & Корневин/контроль & 2.1 & 0.3 & 7.04 & Значим \\
\hline & Эпин/контроль & 1.5 & 0.3 & 5.18 & Значим \\
\hline \multirow[t]{2}{*}{ Зеленая Дымка } & Корневин/контроль & 1.9 & 0.6 & 3.50 & Значим \\
\hline & Эпин/контроль & 1.4 & 0.7 & 1.93 & Не значим \\
\hline \multirow[t]{2}{*}{ Лентяй } & Корневин/контроль & 1.4 & 0.3 & 5.10 & Значим \\
\hline & Эпин/контроль & 1.6 & 0.3 & 5.07 & Значим \\
\hline
\end{tabular}


Процесс укоренения соответствовал принятому стандарту, согласно которому не менее $60 \%$ высаженных черенков должно быть укоренено. При этом укоренение черенков в стимуляторах и контроле отличалось друг от друга незначительно. Применение корневина и эпина оказывает благоприятное воздействие на укореняемость и приживаемость черенков. На этапе укоренения оно выражено более ярко, чем на этапе приживаемости.

Выбор стимулятора для получения максимального числа прижившихся черенков зависит от сорта смородины: корневин целесообразно использовать при размножении сортов Сеянец Голубки и Вологда, эпин - Наследница и Зеленая Дымка, контроль - Лентяй (рис. 2).

В то же время количественно показатель приживаемости существенно превысил предполагаемые значения - по сравнению со стандартом в $40 \%$ от посаженных черенков - у сортов, наименее успешно показавших себя, прижилась почти половина черенков, а наилучшие сорта прижились со средним показателем в 50 \% во всех трех средах и почти в $60 \%$ - в стимуляторах корнеобразования.

Решающее значение о выводах относительно роли стимуляторов корнеобразования в зеленом черенковании сортов смородины черной имеют количественные подсчеты числа и длины образовавшихся корней на черенках в соответствии с методикой обработки данных.

Число корней нулевого порядка у рассматриваемых сортов смородины черной зависит от применения стимуляторов корнеобразования и у ряда из них оно оказывает дополнительное положительное воздействие на образование корней первого порядка. Рост числа корней нулевого порядка статистически значим для всех сортов, данное свойство наиболее ярко выражено в части стимуляторов у корневина, в части сортов - у Наследницы и Лентяя. Средняя длина корня нулевого порядка у черенка в общем случае также зависит от применения стимуляторов, но исключением является сорт Вологда, у которого длина корня черенка не зависит от применения стимулятора. Для черенков данного сорта применение стиму- ляторов вместо дистиллированной воды не приводит к существенно лучшему результату в части роста средней длины корня нулевого порядка. Длина корней нулевого порядка у сорта Зеленая Дымка была больше после применения корневина. Как и в части числа корней, зависимость длины корней от стимуляторов отчетливо проявляется у сортов Наследница и Лентяй.

Результаты проведенного исследования позволяют выполнить группировку изучаемых сортов смородины черной в зависимости от характера приживаемости их черенков и роли стимуляторов в образовании числа и длины их корней (табл. 3). Пять сортов были разделены на три группы, где первая группа включала бы сорта, наиболее перспективные для выращивания в условиях климата среднетаежной подзоны Республики Коми. Сорт оценивали как более перспективный, если он демонстрировал высокую степень приживаемости, а параметры корнеобразования (число и длина корней) оказывались нечувствительными к стимулятору корнеобразования. В этом случае у сорта существует больший потенциал роста корнеобразования.

Корневин и эпин оказались важными факторами образования корней нулевого порядка по всем рассматриваемым сортам, поэтому сорта группировали по характеру приживаемости черенков и роли стимуляторов для показателя средней длины корня нулевого порядка.

Почти все сорта со средней или высокой степенью укореняемости продемонстрировали хорошую приживаемость. В то же время сорт Лентяй показал в опыте относительно высокую степень укореняемости, но низкую - приживаемости, и был помещен в третью группу. Кроме этого, Лентяй оказался весьма чувствительным к стимуляторам, как и сорт Наследница, и последний также попал в третью группу. $К$ ним был присоединен сорт Зеленая Дымка как менее зависимый от стимуляторов, но показавший низкую приживаемость.

Сорта Вологда и Сеянец Голубки характеризуются высокой приживаемостью, но первый по результатам опыта оказался наиболее устойчивым к стимуляторам, что позволяет охарактеризовать его как наиболее перспективный для вы-

Группировка сортов смородины черной в зависимости от влияния стимуляторов

Таблица 3 на укореняемость и приживаемость

\begin{tabular}{|c|c|c|c|c|c|c|c|}
\hline \multirow[t]{2}{*}{ Группа } & \multirow[t]{2}{*}{ Сорт } & \multicolumn{2}{|c|}{$\begin{array}{c}\text { Количественная } \\
\text { характеристика, } \\
\text { в среднем, в \% }\end{array}$} & \multicolumn{2}{|c|}{$\begin{array}{c}\text { Качественная } \\
\text { характеристика }\end{array}$} & \multicolumn{2}{|c|}{ Роль стимуляторов для } \\
\hline & & $\mathrm{y}^{*}$ & $\Pi$ & $\mathrm{y}$ & $\Pi$ & $\begin{array}{c}\text { длины корней } \\
\text { нулевого порядка }\end{array}$ & $\begin{array}{c}\text { числа корней } \\
\text { нулевого порядка }\end{array}$ \\
\hline $1-9$ & Вологда & 72.3 & 53.8 & Средняя & Высокая & Не важны Корн и Э** & Важны Корн и Э \\
\hline 2-я & Сеянец Голубки & 74.5 & 56.3 & Средняя & Высокая & Важен Э & Важны Корн и Э \\
\hline \multirow[t]{3}{*}{ 3-я } & Зеленая Дымка & 66.1 & 50.0 & Низкая & Низкая & Важен Корн & Важны Корн и Э \\
\hline & Наследница & 79.7 & 53.8 & Высокая & Высокая & Важны Корн и Э & Важны Корн и Э \\
\hline & Лентяй & 77.0 & 48.1 & Высокая & Низкая & Важны Корн и Э & Важны Корн и Э \\
\hline
\end{tabular}

* У - укореняемость, П - приживаемость, оба в среднем по двум стимуляторам.

** Корн - корневин, Э - эпин. 
ращивания в условиях климата среднетаежной подзоны Республики Коми с учетом изучаемых в данной работе признаков (показателей размножения зеленым черенкованием).

Корневин и эпин, будучи экологически относительно безопасными препаратами, подтвердили свою эффективность в качестве стимуляторов корнеобразования при зеленом черенковании сортов смородины черной в среднетаежной подзоне Республики Коми. При этом их наиболее эффективное применение требует избирательного подхода с учетом конкретного сорта смородины. Так как для наиболее перспективных сортов - Сеянец Голубки и Вологда - применение корневина приводит к получению максимального числа прижившихся черенков, корневин можно оценить как относительно (по сравнению с эпином) более эффективный стимулятор корнеобразования.

Полученные результаты опыта могут оказаться смещенными в сторону занижения роли применяемых стимуляторов в силу того, что возраст маточных растений для исследуемых черенков составил 19-20 лет вместо рекомендуемых 5-12 лет. Более молодые побеги могут быть чувствительнее к стимуляторам корнеобразования.

Помимо более пристального внимания к растениям - источникам черенков, для более достоверных оценок влияния стимуляторов требуется регистрация наблюдений в течение нескольких сезонов с особым вниманием к погодным условиям и их влиянию на корнеобразование. Это требует расширения временного периода исследований и продолжения его в последующих сезонах.

\section{Выводы}

Результаты оценки характера влияния стимуляторов корнеобразования на приживаемость зеленых черенков смородины черной в средней подзоне тайги Республики Коми позволяют сформулировать следующие выводы:

- показатели укоренения и приживаемости черенков соответствовали, а по некоторым сортам превысили стандартные значения;
- эффект действия стимуляторов на укоренение и приживаемость зеленых черенков положителен и различается в зависимости от сорта смородины;

- применение стимуляторов влияет на образование корней нулевого порядка у всех сортов (в части числа корней);

- у некоторых сортов стимуляторы вызывают дополнительное образование корней первого порядка;

- применение стимуляторов влияет на среднюю длину корня нулевого порядка, но не у всех сортов и не для обоих стимуляторов. В частности, у сорта Вологда длина корня не зависит от применения стимулятора.

Таким образом, стимуляторы корнеобразования корневин и эпин при зеленом черенковании сортов смородины черной в среднетаежной подзоне Республики Коми эффективны при использовании в вегетативном размножении зелеными черенками. Сорт Вологда оценен как наиболее перспективный для выращивания с учетом изучаемых в данной работе признаков.

Исследования выполнены в рамках государственного задания по теме «Закономерности процессов репродукиии ресурсных растений в культуре на европейском Северо-Востоке» № АAАA-A17-117122090004-9.

\section{ЛИТЕРАТУРА}

Аладина, О. Н. Оптимизация технологии зеленого черенкования садовых растений / О. Н. Аладина // Известия TCXА (Генетика, селекция и семеноводство, биотехнология, физиология растений). -2013 . - № 4 . C. $5-22$.

Атлас ареалов и ресурсов лекарственных растений СССР. - Москва : Картография, 1983. - 340 с.

Атлас по климату и гидрологии Республики Коми. Москва : Дрофа; ДИК, 1997. - 116 с.

Батыгина, Т. Б. Размножение растений / Т. Б. Батыгина, В. Е. Васильева. - Санкт-Петербург : Изд-во Санкт-Петербургского университета, 2002. - 232 с.

Витковский, В. Л. Плодовые растения мира / В. Л.

Витковский. - Санкт-Петербург : Лань, 2003. - 592 с. Доспехов Б. А. Методика полевого опыта (с основами статистической обработки результатов исследований) / Б. А. Доспехов. - 5-е изд. - Москва : Агропромиздат, 1985. - С. 193-194.

Средняя длина корня нулевого порядка одного черенка, см*

Приложение

\begin{tabular}{|c|c|c|c|c|c|c|c|c|c|c|c|c|c|c|c|}
\hline \multirow{2}{*}{$\frac{\text { Показатель }}{\text { Черенок }}$} & \multicolumn{3}{|c|}{ Сеянец Голубки } & \multicolumn{3}{|c|}{ Зеленая дымка } & \multicolumn{3}{|c|}{ Вологда } & \multicolumn{3}{|c|}{ Наследница } & \multicolumn{3}{|c|}{ Лентяй } \\
\hline & Kop & $\ni$ & $\mathrm{KOH}$ & Kop & $\ni$ & $\mathrm{KoH}$ & Kop & $\ni$ & $\mathrm{KoH}$ & Kop & $\ni$ & $\mathrm{KOH}$ & Кор & $\ni$ & $\mathrm{KoH}$ \\
\hline 1 & 4.6 & 10.9 & 5.5 & 7.7 & 9.3 & 6.2 & 9.1 & 7.7 & 6.6 & 8.9 & 9.2 & 7.0 & 8.2 & 8.4 & 6.5 \\
\hline 2 & 8.2 & 9.8 & 5.1 & 9.4 & 7.4 & 7.0 & 7.6 & 6.9 & 9.3 & 9.5 & 8.8 & 7.5 & 8.1 & 8.1 & 7.3 \\
\hline 3 & 5.1 & 6.3 & 4.2 & 8.2 & 7.0 & 6.3 & 8.9 & 6.7 & 10.5 & 9.7 & 8.3 & 7.2 & 8.3 & 8.7 & 6.5 \\
\hline яя (X сp.) & 6.0 & 9.0 & 5.0 & 8.4 & 7.9 & 6.5 & 8.5 & 7.1 & 8.8 & 9.4 & 8.8 & 7.2 & 8.2 & 8.4 & 6.8 \\
\hline Стан & 1. & 2.4 & 0.6 & 0. & 1.2 & 0.4 & 0.8 & 0.5 & 2.0 & 0.4 & 0.4 & 0.3 & 0.1 & 0.3 & 0.5 \\
\hline Стандартная ошибка & 1.1 & 1.4 & 0.4 & 0.5 & 0.7 & 0.2 & 0.5 & 0.3 & 1.2 & 0.3 & 0.3 & 0.2 & 0.0 & 0.2 & 0.3 \\
\hline \multicolumn{16}{|c|}{ Справочно (по трем черенкам) } \\
\hline $\begin{array}{l}\text { Суммарная длина корня } \\
\text { нулевого порядка }\end{array}$ & 2118 & 2086 & 848 & 1430 & 1104 & 625 & 3824 & 2028 & 1708 & 3034 & 2350 & 1245 & 2034 & 1466 & 783 \\
\hline $\begin{array}{l}\text { Число корней } \\
\text { нулевого порядка, ед. }\end{array}$ & 358 & 235 & 169 & 171 & 141 & 97 & 450 & 286 & 199 & 324 & 268 & 172 & 248 & 175 & 116 \\
\hline Число корней & 4295 & 2638 & 1433 & 1578 & 1486 & 988 & 5158 & 2936 & 1743 & 2869 & 2685 & 1737 & 2243 & 1618 & 1018 \\
\hline
\end{tabular}

перв ого порядка, ед.

\footnotetext{
${ }^{*}$ Кор - корневин, Э - эпин, Кон - контроль (вода).
} 
Жулева, В. М. Ягодные кустарники / В. М. Жулева, Л. Г. Черенок. - Москва : Издательский Дом МСП, 2005. -240 c.

Мартыненко, В. А. Сем. 48. Grossulariaceae DC. Крыжовниковые / В. А. Мартыненко // Флора северовостока европейской части СССР. - Т. 3. - Семейства Nymphaeaceae - Hippuridaceae. - Ленинград : Наука, 1976. - C. $100-104$.

Мартыненко, В. А. Сосудистые растения Республики Коми / В. А. Мартыненко, Б. И. Груздев. - Сыктывкар : Коми НЦ УрО РАН, 2008. - 136 с.

Огольцова, Т. П. Селекция черной смородины прошлое, настоящее, будущее / Т. П. Огольцова. - Тула : Приокское книжное изд-во, 1992. - 384 с.

Плеханова, М. Н. Маточные насаждения и технология размножения синей жимолости (методические указания) / М. Н. Плеханова. - Ленинград : ВНИИР им. Н. И. Вавилова, 1989. - 34 с.

Поздняков, А. Д. Смородина / А. Д. Поздняков. Москва : Агропромиздат, 1985. - С. 72-74.

Рязанова, Л. Г. Основы статистического анализа результатов исследований в садоводстве / Л. Г. Рязанова, А. В. Проворченко, И. В. Горбунов. - Краснодар : Кубанский государственный аграрный университет, 2013. - С. 5-15.

Стрельцов, Ф. Ф. Совершенствование технологии производства посадочного материала плодовых и ягодных культур / Ф. Ф. Стрельцов, Р. А. Тучин // Достижения науки и техники АПК. - 2008. - № 7. - С. 2426.

Тимушева, О. К. Роль эпин-экстра в зеленом черенковании смородины черной в подзоне средней тайги Республики Коми / О. К. Тимушева, К. С. Зайнуллина // Актуальные проблемы экологии : материалы VIII международной научно-практической конференции, 24-26 октября 2012 г., Гродно. - Гродно : ГрГУ им. Я. Купалы, 2012. - С. 70-72.

Anthocyanin-rich black currant (Ribes nigrum L.) extract affords chemoprevention against diethylnitrosamine-induced hepatocellular carcinogenesis in rats / A. Bishayee [et al.] // The Journal of Nutritional Biochemistry. - 2011. - Vol. 22, iss. 11. - P. 1035-1046.

Antioxidant and anti-inflammatory activities of Ribes nigrumextracts / J. Tabart [et al.] / / Food Chemistry. 2012. - Vol. 131, iss. 4. - P. 1116-1122.

Antioxidant lignoids from leaves of Ribes nigrum / T. Sasaki [et al.] // Phytochemistry. - 2013. - Vol. 95. P. 333-340.
Bakowska-Barczak, A. M. Black currant polyphenols: Their storage stability and microencapsulation / A. M. Bakowska-Barczak, P. P. Kolodziejczyk // Industrial Crops and Products. - 2011. - Vol. 34, iss. 2. - P. 13011309.

Effects of controlled post-flowering temperature and daylength on chemical composition of four black currant (Ribes nigrum L.) cultivars of contrasting origin / T. L. Woznicki [et al.] // Scientia Horticulturae. - 2015. Vol. 197. - P. 627-636.

High variability in flavonoid contents and composition between different North-European currant (Ribes spp.) varieties / P. H. Mattila [et al.] // Food Chemistry. 2016. - Vol. 204, N. 1. - P. 14-20. doi: 10.1016/ j.foodchem.2016.02.056

Influence of shading net on polyphenol profile and radical scavenging activity in different varieties of black currant berries / K. Savikin [et al.] // Scientia Horticulturae. - 2013. - Vol. 160, N. 27. - P. 20-28.

Liu, P. Flavonol glycosides and other phenolic compounds in buds and leaves of different varieties of black currant (Ribes nigrum L.) and changes during growing season / P. Liu, H. Kallio, B. Yang // Food Chemistry. 2014. - Vol. 160, N. 1. - P. 180-189. doi: 10.1016/ j.foodchem.2014.03.056

Major phenolic compounds in black currant (Ribes nigrum L.) buds: Variation due to genotype, ontogenetic stage and location. $L W T$ / M. Vagiri [et al.] // Food Science and Technology. - 2015. - Vol. 63, iss. 2. P. 1274-1280.

Pomological and biochemical characterization of European currant berry (Ribes sp.) cultivars / B. Djordjevic [et al.] // Scientia Horticulturae. - 2014. - Vol. 165, N. 22. - P. 156-162.

Protective effects of black currant (Ribes nigrum L.) extract on hydrogen peroxide-induced damage in lung fibroblast MRC-5 cells in relation to the antioxidant activity / N. Jia [et al.] // Journal of Functional Foods. 2014. - Vol. 11. - P. 142-151.

Radical scavenging activity of black currant (Ribes nigrum L.) extract and its inhibitory effect on gastric cancer cell proliferation via induction of apoptosis / N. Jia [et al.] // Journal of Functional Foods. - 2012. Vol. 4, iss. 1. - P. 382-390.

Variations in the essential oil composition in buds of six blackcurrant (Ribes nigrum L.) cultivars at various development phases / A. Dvaranauskaite [et al.] // Food Chemistry. - 2009. - Vol. 114, iss. 2. - P. 671-679.

\title{
THE USE OF ROOT STIMULANTS IN GREEN CUTTING OF VARIETIES OF BLACK CURRANT IN THE MIDDLE-TAIGA SUBZONE OF THE KOMI REPUBLIC
}

\author{
O.K. Timusheva \\ Institute of Biology of Komi Scientific Centre of the Ural Branch of the Russian Academy of Sciences, Syktyvkar
}

Summary. Results of vegetative reproduction of five varieties of black currant (Ribes nigum L.) of Altai ( Sejanec Golubki»), Moscow («Vologda» and «Naslednica»), Michurinsk («Zeljonaja Dymka») and Orel («Lentjaj») selections in 2016 by the method of green cutting are presented. Root stimulators Kornevin and Epin-extra (Epin) were used to assess their influence on survival rate of green cuttings of the varieties.

Kornevin and Epin are confirmed to be effective root stimulators in green cutting of cultivars of black currant in the climatic conditions of the Komi Republic. More than $60 \%$ of the planted green cuttings were rooted that is in accordance with the standard. The survival rate of cuttings exceeded the standard value and the best varieties engrafted with an average of $50 \%$ in all three media and almost $60 \%$ in root stimulators.

Taking into account the features discussed in our paper, variety Vologda is considered to be the most promising for cultivation in climatic conditions of the Komi Republic. It has high survival rate and is most resistant to stimulators, which indicates its growth potential of root development and overall resistance to the severe climatic conditions of the northern region.

To confirm the reliability of the obtained results, it is necessary to study the model varieties of black currant during the next few seasons with a special attention to the weather conditions and the influence of them on the rooting.

Key words: black currant, vegetative reproduction, green cutting, Kornevin, Epin-ekstra, rooting, root-survival 